\title{
Analysis of City Greening Approach to Sustainable Ecosystem Management in Ondo State
}

\author{
Adebo G. M (Corresponding author) \\ Department of Agricultural Economics and Extension Services \\ Ekiti State University, PMB 5363, Ado-Ekiti, Nigeria \\ E-mail: grace.adebo@eksu.edu.ng
}

Odefadehan O. O

Department of Agricultural Extension and Communication Technology

Federal University of Technology, Akure

Received: February 4, 2015 Accepted: March 1, 2015

doi:10.5296/emsd.v4i1.7047 URL: http://dx.doi.org/10.5296/emsd.v4i1.7047

\begin{abstract}
The study was carried out to access the "City Greening: A House a Tree" programme of the Ondo state government. Multistage and simple random sampling techniques were used to select 80 respondents utilized for the study while frequency counts and percentages, as well as Pearson Product Moment Correlation, were used in data analysis. The study shows that most of the respondents interviewed were young, married, literate and dominated by Male headed households. Most of them were aware of the tree planting programme through Government officials/ Agricultural Extension agents. The various levels of participation include obtaining seedlings from Ministry of Environment (MOE), Sensitization and Mobilization, Planting of trees, watering of trees and given moral support. Tree species mostly planted are Step by step (Terminalia mentabris) and Tropical Almond (terminalia catapa). Others are meilgna tree (Gmeligna arborea), fruits /Oranges, (thuja orientals) and Masquerade tree (polyathia longifolia). Most of them planted three to six seedlings, and the rate of survival was very high. The benefits derived from the trees includes: protecting the building from been blown off by wind and reducing excessive environmental heat. It also helped in reducing erosion, creating the opportunity for pleasure and providing food for man/ animals respectively. The highest constraints to the survival of tree planting programme in Ondo state is destruction by domestic animals, followed by lateness in obtaining seedlings from the MOE. The study established a significant relationship between city greening program and sustainable ecosystem
\end{abstract}


management. The study recommends continuous promotion of the program through the use of extension agents, television and radio programmes and the enforcement of Legislations for sustainable ecosystem management.

Keywords: Ecosystem, Environment, Erosion, Sustainability, Tree planting

\section{Introduction}

Sustainable development and wealth of several countries of the World are still measured in economic terms with the neglect of the values of the ecosystems. However, UNEP (2013) stressed the dependence of Human well-being on the health of ecosystems. An ecosystem is a dynamic complex of plants, animals, micro-organisms and their non-living environment, of which people are an integral part. According to the International Union for Conservation of Nature IUCN (2013), the ecosystem provides various goods and services for human survival. Such includes food, fuel, construction materials, clean water and air, and protection from natural hazards. It is imperative to note that all the benefits that man derive from nature and rely on every day, from timber and food to water and climate regulation, are all ecosystem services (UNEP, 2013). Sustainable development according to World Commission on Environment and Development (WCED, 1987) refers to the economic and social development that meets the needs of the current generation without undermining the ability of future generations to meet their own needs. Thus, the three pillars of sustainable development to consider are economic development, social development and ecological development. According to Costzana and Principe (1992) the health of the ecosystem is very germane to its sustainability. Haskell et al., (1992) opined that an ecological system is healthy and free from distress syndrome, if it is active, and maintains its organization and autonomy over time, and is resilient to stress (Forest health, 2015). There is the need to assess the ecological health across scales, space and time for sustainable development.

Despite the relevance of the ecosystem to life, UNEP (2012) affirmed that the ecosystems are under unprecedented pressure and threatening prospects for sustainable development. Also, IUCN (2013) asserted that the ecosystems are under increasing pressure from unsustainable use and other threats including outright conversion.

To correct the hazard, several researchers have advocated the use of the Ecosystem Approach (IUCN, 2013 UNEP, 2012, EMI, 2014). Ecosystems management is an approach to natural resource management that focuses on sustaining ecosystems to meet both ecological and human needs in the future.

According to (Cornett, 1994), 'Ecosystem management defines a paradigm that weaves biophysical and social threads into a tapestry of beauty, health, and sustainability. It embraces both social and ecological dynamics in a flexible and adaptive process. Ecosystem management celebrates the wisdom of both our minds and hearts, and lights our path to the future.'

The IUCN view ecosystem management approach as a process that integrates ecological, 
socioeconomic, and institutional factors into comprehensive analysis and action in order to sustain and enhance the quality of the ecosystems to meet current and future needs.

Ecosystem management uses an ecosystem-based approach to resource management in order to address the myriad challenges that arise from fragmented landscapes and diverse management strategies. It promotes shared vision of a desired future by integrating social, environmental and economic perspectives to managing geographically defined natural ecological systems. It is management that is adaptive to changing needs and new information. It also provides innovative opportunities for local communities, business and government to benefit communities, economies and the global environment. It could provide a cost-efficient and effective way to reduce the impacts of climate change if managed properly.

An ecosystem management approach according to EMI (2014) has five key elements. Ecosystem management:

- Requires consideration of geographic areas defined by ecological boundaries and the perspectives provided by different spatial scales and longer time frames.

- Requires the consideration of the complex natural processes and social systems for effective management

- Incorporates explicit definition of biological and social goals at both the national and local scales and elevates maintenance and restoration of ecological sustainability and ecosystem integrity as important goals.

- Emphasizes collaborative decision-making to deal with a landscape owned by many individuals and organizations with different values, interests and capabilities.

- Uses a process of adaptive management to account for the uncertainty inherent in our understanding and the future, and employs a wide range of strategies and policy tools.

In order to secure the environmental conditions for prosperity, stability and equity, timely responses that are proportionate to the scale of the environmental challenges are germane. Such responses required role performance by all the stakeholders in the environment. The stakeholders include: the governments, the international community, the private sector, civil society and the general public.

In recent times, the rate of deforestation in Ondo State is very high. It is due to Urbanization and the necessity to feed the growing population. Urbanization, according to Nancy et al. (2008) is an important driver of climate change and pollution. Climate change alters both biotic and abiotic ecosystem properties within, surrounding, and even at great distances from urban areas. Regardless of the rates of deforestation in the urban or rural areas, studies reveal changes in rainfall patterns, temperature, flooding, soil temperature, relative humidity compared to what was obtainable some 20-30 years ago. Also, Hales (2000) affirmed that the increasing urban population has contributed to industrial, human wastes and effluents resulting in noise, air, water, and land pollutions. It causes the urban heat and urban sprawl leading to loss of green area. 
Sometimes ago, a certain part of the urban centers of Ondo State, Nigeria, witnessed unprecedented heavy downpour and wind storm. It negatively impacted the people as several houses were submerged in floods, several roof blown off, and rivers overflow their banks across the state. An attempt to address the situation and forestall further occurrence led to the initiation of a 'City Greening- A House, a Tree' programme by the Ondo State Government in the year 2010. The Benefits of Urban Trees include: reduces air pollution; fights the atmospheric greenhouse effects and conserves and reduces soil erosion. It also saves energy; modifies local climate; increases economic stability; reduces noise pollution and creates wildlife and plant diversity (Maryland Department of Natural Resources, 2013) and Nix (2014). United States Department of Agriculture (USDA) Forestry services (1990) also add that trees increases property values and lower air temperature through shade. It also increases humidity in dry climates through evaporation of moisture; reduce glare on sunny days; reduce wind speed; add natural character to cities and towns. It also provides the environment with colours, flowers, and beautiful shapes, forms and textures and Screen harsh scenery. Trees soften the outline of masonry, metal and glass and can be used architecturally to provide space definition and landscape continuity; while tree roots hold soil in place and increases water infiltration

The most effective mitigating measure against climate change is planting of trees. Reforestation and agroforestry systems offer the greatest potential to remove large quantities of carbon from the atmosphere. Such offsets are the only way to remove current atmospheric carbon dioxide as all other mitigating measures can only reduce future emissions (carbon2markets, 2014).

The city greening programme was overseen by the state Ministry of Environment in conjunction with the State Department of Forestry. Though the programme was tagged "City Greening: A House a Tree". The programme was meant to cover the entire state; cities, towns and villages. The overall goal of the programme is to ensure that at least a tree is planted per house in Ondo state. The purpose of serving as climate change mitigating measure; improving the aesthetic value of the environment; source of empowerment for youth; provide medicinal plants and serving as fodder for animals. All these are necessary to ensure the sustainable development of the environment. The ministry of environment worked strategically with: Individuals, Non-governmental organizations, Schools (Primary, Secondary and Tertiary), Religious Organizations and Local Government Areas. The targeted audience got free seedlings of various trees from the ministry of environment, who in turn got seedlings from the Department of Forestry and Natural Resources.

Despite the significance of this programme, several households in the Urban and rural areas of Ondo state are still without trees. One begin to wonder why this is so. Some pertinent questions came to mind, among which are:

- Are the residents of the state aware of the City Greening programme?

- If yes, what proportions of them are aware and what are their source(s) of information?

- How do they perceive the program/ of what significance do they view the programme?

-What proportion of the rural and urban residents participated in the city greening programmes 


\section{Ml Macrothink}

since inception?

- What are the species of trees planted?

- What is the survival rates of the trees planted?

-What are the benefits derived so far from the programme by the residents?

-What are the constraints to the city greening programme in Ondo State?

- Is there any relationship between the City greening programme and sustainable ecosystem management?

Responses to these questions will authenticate if the City greening programme of Ondo state government has any significance to the sustainability of the ecosystem or not.

The study is of paramount importance because developmental activities in Ondo state have excluded the links between the ecosystem sustainability and development. Though the city programme was initiated by the state government, the contributions to the ecosystem have not been measured to showcase the necessity for the programme or otherwise. The findings from the study will generate policy statements required for sustainable ecosystem management using the city greening approach.

The materials and methods used in the study are discussed in the next section. It is followed by the discussion of results as well as the summary, conclusion and recommendations for policy interventions.

\section{Methodology}

The entire Ondo state constitutes the population for the study. However, the sampling frame was arrived at through a multi-stage, and simple random sampling techniques. A multi-stage sample according to Battaglia (2008) is one in which sampling is done sequentially across two or more hierarchical levels. These are; the county level, the census track level, the block level, the household level, and ultimately at the within-household level. The population in multi-stage sampling according to FAO (1997) is regarded as being composed of a number of the first stage or Primary Sampling Units (PSU's). Each of them comprises a number of the second stage units in each selected PSU, and so the procedure continues down to the final sampling unit.

The first stage involves a random selection of two Local Government Areas (LGA from 18 LGAs in the state. The second stage involves a random selection of two rural communities and two towns from each of the selected LGA. The final stage involves a random selection of ten households from the communities and towns, thus making a total of eighty households. Also, four secondary schools and the two Universities in the state were visited to investigate their compliance with the city greening programme.

A simple random sampling technique was used for the final selection of the respondents in order to ensure that all the members of the population has equal chances of being selected. It avoids bias in selection. 


\section{Ml Macrothink}

The data used for the study was collected through a structured interview schedule, and it was analyzed using descriptive statistics such as frequency counts and percentages and inferential statistics such as the Pearson Product Moment Correlation.

\section{Results and Discussion}

\subsection{Socio-economic Characteristics of the Respondents}

Data in Table 1 shows that the majority (62.5\%) of the respondents were within 41-50 years of age, 17.5 percent were within 31-40 years old while 8.8 percent were within 51-60 years of age. The mean age of the respondents was 44.6 years, an indication that most of the respondents are in the active and productive age. They are still agile and as such are expected to participate in activities relevant to the sustainability of their environment. A huge percentage $(81.3 \%)$ of the respondents' households was headed by a male while $18.8 \%$ were female-headed households. It was similar to the findings of Mohammed-Lawal et al. (2012) study of household vulnerability to economic shocks in Ondo state, where 80.1 percent of the households sampled were male headed households. Also, 80 percent of the respondents were married; 10 percent were divorced while five percent were widowed / single respectively. Over 70 percent of the respondents completed one form of tertiary education or the other while those that attempted and completed secondary school education were 1.3 percent respectively. It shows that most of the respondents were literate. The high literacy level is expected to influence their access to information as well as participation in programs desired to maintain the ecosystem.

Table 1. Distribution of the Socio-economic Characteristics of the Respondents

\begin{tabular}{|l|l|l|}
\hline Socio economic variables & Frequency & percentages \\
\hline Sex & 65 & 81.3 \\
\hline Male & 15 & 18.7 \\
\hline Female & \multicolumn{2}{|l|}{} \\
\hline \multicolumn{3}{|l|}{} \\
\hline Marital Status & 04 & 5.0 \\
\hline Single & 64 & 80.0 \\
\hline Married & 08 & 10.0 \\
\hline Divorced & 04 & 5.0 \\
\hline Widowed & 09 & 11.2 \\
\hline Age & 14 & 17.5 \\
\hline $20-30$ & 50 & 62.5 \\
\hline $31-40$ & 07 & 8.8 \\
\hline $41-50$ & 01 & 1.3 \\
\hline $51-60$ & 01 & 1.3 \\
\hline Highest Educational level & \multicolumn{2}{|l|}{} \\
\hline Attempted Secondary school & 01 & 22.5 \\
\hline Completed Secondary school & 01 & 75.0 \\
\hline Attempted Tertiary Education & 18 \\
\hline Completed Tertiary Education & 60 & \\
\hline \multicolumn{2}{|l|}{} \\
\hline
\end{tabular}

Source: Field Survey, 2014

\subsection{Awareness of City Greening Programme}

Figure 1 shows that 68.8 percent of the respondents were aware of the city greening 


\section{Macrothink}

Environmental Management and Sustainable Development

ISSN 2164-7682 2015, Vol. 4, No. 1

programme while 31.3 percent claimed they were not aware of the programme. The greater percentage of the respondents being aware of the programme could be due to the sensitization campaign by the Ondo state Ministry of Environment in collaboration with Department of Forestry in the Ministry of Agriculture. These two ministries employed several methods to create awareness on the programme. The 31.3 percent claiming not to be aware of the programme might result from inadequate utilization of local media to receive information. It is worth noting that all the secondary schools and Universities visited were aware of the programme

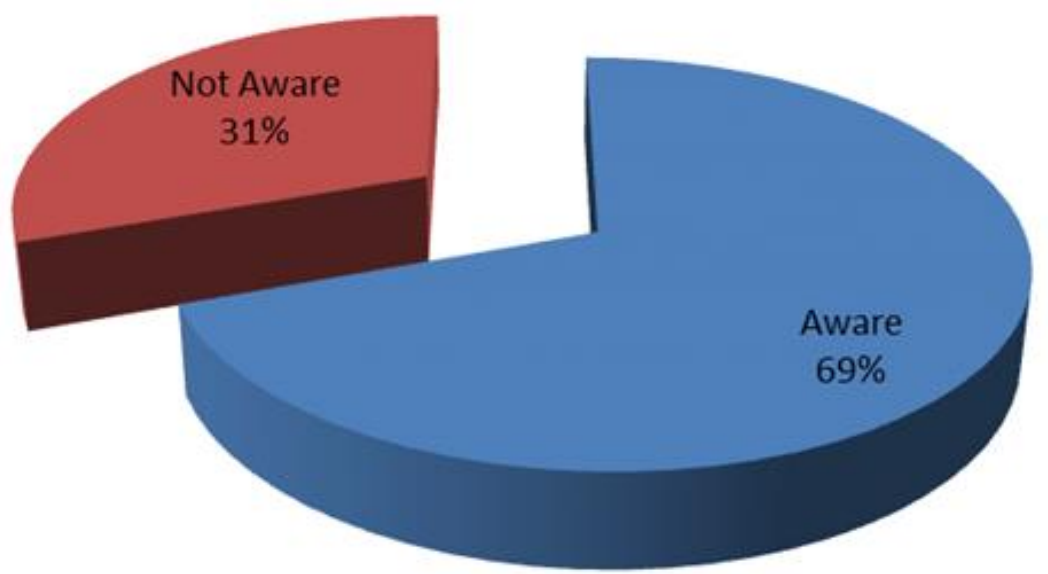

Figure 1. Awareness of city Greening programme

\subsection{Span of Awareness of City Greening Programme}

Concerning the span of awareness, a greater percentage of the respondents $(66.25 \%)$ knew of the programme about 3-4 years ago. $28.75 \%$ knew about it 1-2years ago while $5.0 \%$ discerned the program about a year ago. The awareness trend depicts continuity in the awareness programme put in place by the project organizers. This might influence the sustainability of the programme positively (Figure 2).

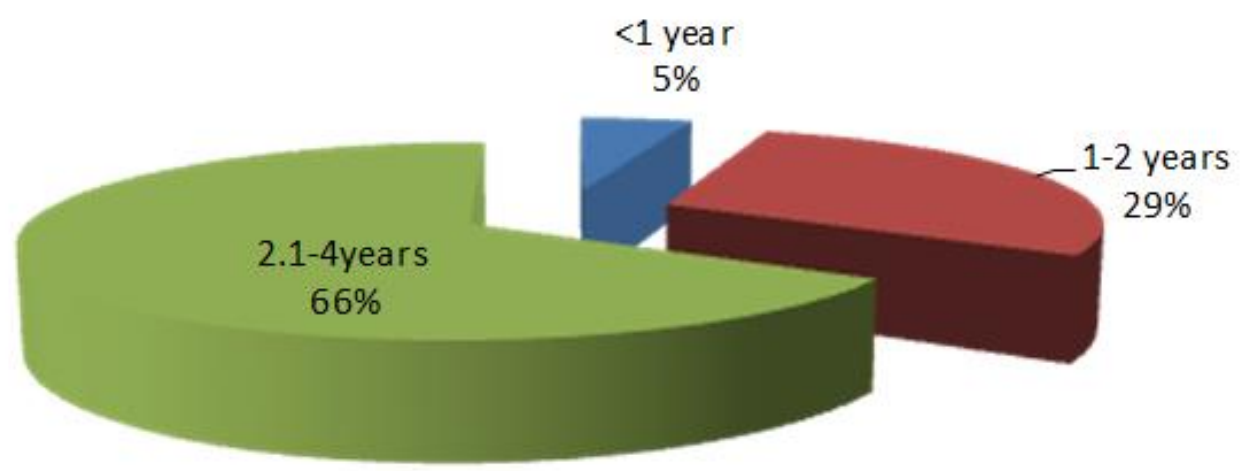

Figure 2. Span of Awareness of City greening programme

Source: Field Survey, 2014

\subsection{Sources of Information on City Greening Programme}




\section{Macrothink}

Table 2 shows that 43.63, 63.64, 72.7 and 32.72 percent of the respondents had about city greening projects through the Television, radio, government official/agricultural extension agents and newspapers as well as family/friends respectively. The major source of information about city greening programme was the Government officials/ Agricultural Extension agents. This discovery is in line with the World Bank's findings that extension agents are the most credible source of information on agricultural technology in Nigeria (World Bank, 1997). However, Okunlola et al. (2011) and Fasakin (2008) had a contrary view. Their study revealed that the majority of the farmers did not have access to extension activities in Ondo state. Other prominent sources of information on city greening program include television, radio, newspapers as well as family and friends. World Bank (1997) also affirms the popularity of television, radio and newspapers as major sources of communicating agricultural technology in Nigeria. The good proportion that had about city greening programme through family and friends might result from the high usage of interpersonal communication in the study area. This finding supports the assertion of Obayelu (2010) and Adebo (2014) that most of the farmers in Nigeria received extension messages mostly through interpersonal communication. Other sources of information such as churches, mosques, cooperatives, billboards and posters recorded very low percentages, an indication that they were hardly used to disseminate information on city greening programme. None of the respondents received information about city greening programme via the town crier and mobile phone. The use of a town crier for information dissemination is gradually fading out in Nigeria. The discovery also contradicts the findings of Falola and Adewumi (2012) that farmers in Ondo state used mobile telephony to receive information about agricultural activities. Also, the uses of Mobile phone to broadcast messages require consultation with the mobile service providers and registration of mobile phones for such services. The city greening initiators may not do this. Hence, it's none usage.

Table 2. Sources of Information on City Greening programme

\begin{tabular}{|lll|}
\hline Information sources & Frequency $(\mathrm{n}=55)$ & percentages \\
\hline Family and friends & 9 & 16.36 \\
Customers/colleagues/market & 2 & 3.63 \\
Town crier & 0 & 0.00 \\
Mobile phone & 0 & 0.00 \\
Cooperative/ civil societies & 5 & 9.0 \\
Church/Mosques & 1 & 1.8 \\
Television & 24 & 43.63 \\
Radio & 35 & 63.64 \\
Government official/agents/Agric. Extension worker & 40 & 72.7 \\
Newspaper/magazine/ Handbills/fliers & 18 & 32.72 \\
Billboard/posters & 3 & 5.45 \\
\hline
\end{tabular}

*Multiple responses

Source: Field Survey, 2014

\subsection{Participation in Tree Planting}




\section{Macrothink}

Data in Table 3 revealed the various levels of participation in tree planting programme. About $11.0 \& 22.5$ percentages of respondents helped in obtaining seedling from ministry of environment \& sensitizing and mobilizing the public for the programme respectively. While 65.0 and 23.8 percentages of respondent's participated in actual tree planting and watering of trees planted respectively. It is worth noting that 13.8 percent of the respondents gave moral support to participants. Also, all the educational institutions participated in the tree planting programme. The various levels of involvement show that the people were actively involved in the tree planting program. The active participation might result from the consequences of flooding being witnessed across the nation at the time. Hence, the high level of awareness created by the ministry of environment on the necessity for tree planting. Also, the actual involvement of the majority $(65.0 \%)$ in tree planting is an indication of the value placed on the project by the people.

Table 3. Level of Participation in Tree planting

\begin{tabular}{|lcl|}
\hline Level of participation & Frequency & Percentages \\
\hline Obtain seedlings from MOE & 8 & 10.0 \\
Sensitization and Mobilization & 18 & 22.5 \\
Planting of trees & 52 & 65.0 \\
Watering of trees & 19 & 23.8 \\
Gave moral support & 11 & 13.8 \\
\hline
\end{tabular}

Source: Field Survey, 2014

\subsection{Species of Trees Planted}

Figure 3 shows the various tree species planted by the respondents. Step by step (Terminalia mentabris) and Tropical Almond (terminalia catapa) were mostly planted by the respondents followed by melgna tree, (16.0\%), fruits /Oranges occupied the third position while thuja orientals came forth. Masquerade tree (polyathia longifolia) came last. The popularity of tropical almond and other fruits /oranges might result from the dual benefits derived from them. Step by step tree is known for its aesthetic values while growing up. This might be the reason for its popularity. Tropical almond and fruits/oranges provide edible fruits and at the same time can protect the environment. The least position occupied by Masquerade tree might result from the tall nature of the tree and the perceived difficulty of maintenance, hence its unpopularity among the people. 

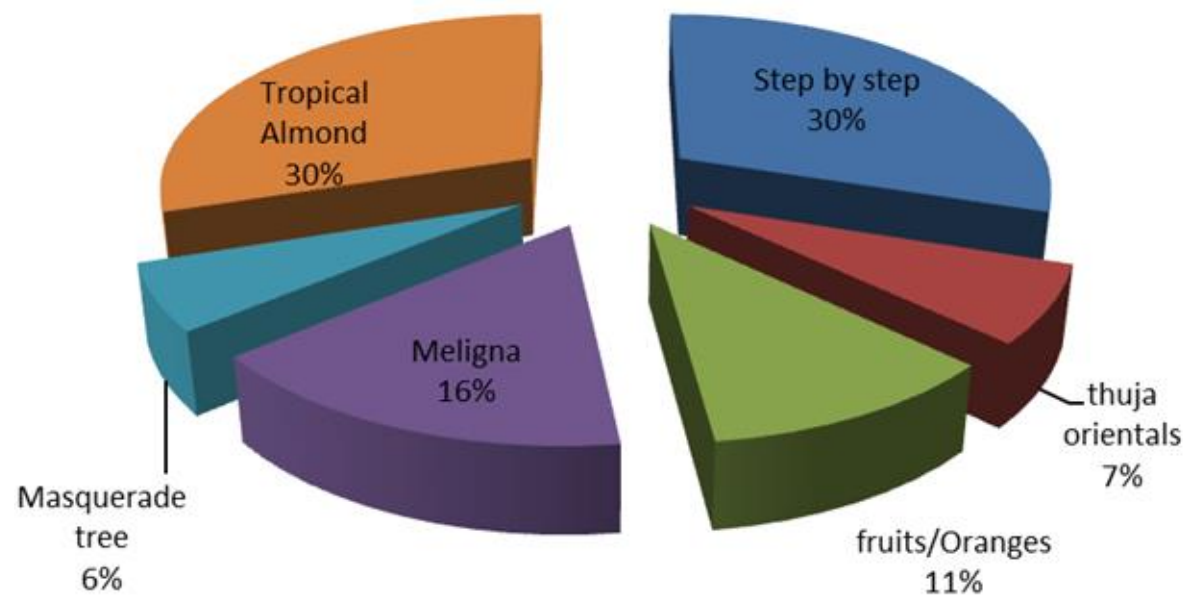

Figure 3. Species of Trees Planted

\subsection{No of Seedlings Planted and Survival Rate}

Data in Table 4 shows that a majority (71.2\%) of the respondents planted 3-6 seedlings of tree in their compounds. Among this category, 57.7 percent of the respondents claimed that 3-6 seedlings survived and are still alive at the time of the survey. About 24 percent of the respondents planted 1-2 trees in their compound while 19.2 percent claimed that $1-2$ seedlings survived. The survival rate of the group that planted above seven seedlings was 9.6 percent. The findings show that most of the seedlings supplied to residences in Ondo state for planting were viable. The high viability level points to the fact that they will contribute significantly to sustainability of the environment.

Table 4. No of seedlings planted and survival rate

\begin{tabular}{|l|l|l|}
\hline No of seedling categories & Frequency (52) & Percentages \\
\hline $1-2$ & 12 & 23.1 \\
$3-6$ & 37 & 71.2 \\
$7-10$ & 2 & 3.8 \\
$>10$ & 1 & 1.9 \\
No of Surviving trees & & \\
$1-2$ & 10 & 19.2 \\
$3-6$ & 30 & 57.7 \\
$7-10$ & 5 & 9.6 \\
\hline
\end{tabular}

Source: Field Survey, 2014

\subsection{Significance of City Greening Programme}

Data in Table 5 shows the diverse usefulness of city greening program to the respondents. Most $(63.8 \%)$ of the respondents agreed that the programme protects the building from been blown off by wind as well as reduces excessive environmental heat respectively. In addition 60.0, 46.3 and 31.3 percent of the respondents indicated that tree planning has helped in reducing erosion, 
creating the opportunity for pleasure and providing food for man/ animals respectively. All other factors recorded very low percentages, indicating their less importance to the programme (Table 6). From the previously stated, the government achieved the aims of city greening program to a considerable extent. All things being equal, if the government is consistent with the implementation of the program, Ondo state will be free from several diverse effects of climate change and wind problems

Table 5. Significance of City greening programme

\begin{tabular}{|l|l|l|}
\hline Significance & Frequencies. & Percentages \\
\hline It helps to reduce erosion & 48 & 60.0 \\
\hline It protects the building roof from wind & 51 & 63.8 \\
\hline It helps in reducing excessive environmental heat & 51 & 63.8 \\
\hline It protects living microbes in the soil & 10 & 12.5 \\
\hline It create opportunity for leisure & 37 & 46.3 \\
\hline It serves as a form of physical exercise & 13 & 16.3 \\
\hline It provides feed for man/animals & 25 & 31.3 \\
\hline It generate employment opportunity & 13 & 16.3 \\
\hline
\end{tabular}

Source: Field Survey, 2014

\subsection{Constraints to Tree Planting}

Data in Table 6 shows the constraints to planting trees by the respondents. These are failure to get seedlings from the Ministry of Environment (36.6\%) and poor quality of seedling (16.3\%). Others are destruction of seedling by domestic animals (53.8\%) and high cost of transportation to obtain seedling (11.3\%). The highest constraints to the survival of tree planting programme in Ondo state is destruction by domestic animals. The rate at which domestic animals roam about in Ondo state is quite alarming. Despite government mandate to provide adequate housing for domestic animals, legislation to back it up was not effective due to weak enforcement, thus posing a great challenge to the environment. Those located in communities far away from the local government headquarters were mostly affected by transportation problems.

Table 6. Constraints to Tree planting programme

\begin{tabular}{|l|l|l|}
\hline Constraints & Frequency & Percent \\
\hline Inability to get seedlings & 29 & 36.3 \\
Poor quality of seedling & 13 & 16.3 \\
Destruction of seedlings by domestic animals & 43 & 53.8 \\
High cost of Transportation to obtain seedlings & 9 & 11.3 \\
\hline
\end{tabular}

Source: Field Survey, 2014

\subsection{Correlation Analysis Showing the Relationship between the City Greening Programme and Sustainable Ecosystem Management}

Data in table 7 shows positive and significant correlations between sustainable ecosystem management and city greening programme at a level of significance of 0.05 in terms of flood 
protection $(r=0.442)$, control of erosion $(r=0.308)$, protection of human life $(r=0.295)$ beautification of landscape $(r=0.199)$, replenishing soil nutrient $(r=0.260)$, providing feed for man and animals $(r=244)$, providing clean water $(r=0.296)$, improving air quality $(r=0.356)$, and improving soil quality $(\mathrm{r}=0.309)$.

The implication of the above findings is that the more trees in the environment, the more it will be protecting the environment. In terms of flood and erosion control, protection of human life, and provisions of feeds for man and animals, replenishing of soil nutrient and improving the quality of air and soil. All these factors will enhance sustainable management of the ecosystem.

Table 7. Correlation Analysis showing the relationship between the City greening programme and sustainable ecosystem management

\begin{tabular}{|c|l|c|}
\hline Variable & Correlation & P-Value \\
\hline Flood protection & $0.442^{* *}$ & 0.000 \\
\hline Control Soil Erosion & $0.308^{* *}$ & 0.295 \\
\hline Protect human life from severe storm & $0.295^{* *}$ & 0.001 \\
\hline Beautify landscape & $0.199^{* *}$ & 0.958 \\
\hline $\begin{array}{c}\text { Provide feed for animal, men and } \\
\text { other economic resources }\end{array}$ & $0.244^{* *}$ & 0.790 \\
\hline Replenish soil nutrient & $0.260^{* *}$ & 0.005 \\
\hline Provide clean water & $0.296^{* *}$ & 0.001 \\
\hline Improves air quality & $0.356^{* *}$ & 0.000 \\
\hline Improve soil quality & $0.309^{* *}$ & 0.001 \\
\hline
\end{tabular}

${ }^{* *}$ Correlation is significant at 0.01 level (2-tailed)

Source: Data Analysis, 2014

\section{Summary, Conclusion and Recommendation.}

\subsection{Summary}

The study was carried out to access the Programme tagged "City Greening: A House a Tree" of the Ondo state government. The programme was initiated to check climate change and sustain the ecosystem. Multistage and simple random sampling techniques were used to select 80 respondents utilized for the study. Four secondary schools and two universities were visited to view compliance with the programme. The study shows that most of the respondents interviewed were young, married, literate and dominated by Male headed households. Most of them were aware of the tree planting programme. The awareness spread over four years. Most of the respondents knew about it when the programme was initiated. The main sources of information were the Government officials/ Agricultural Extension agents. Others are television, radio and newspapers. The various levels of participation include obtaining seedlings from MOE, Sensitization and Mobilization, Planting of trees, watering of trees and given moral support. Tree species mostly planted are Step by step (Terminalia mentabris) and Tropical Almond (terminalia catapa). Others are melgna tree, fruits /Oranges, thuja orientals 
and Masquerade tree (polyathia longifolia). Most of them planted three to six seedlings and the rate of survival was very high. The study shows the diverse usefulness of city greening program to the respondents. These includes: protecting the building from been blown off by wind and reducing excessive environmental heat. In addition tree helped in reducing erosion, creating opportunity for pleasure and providing food for man/ animals respectively. The highest constraints to the survival of tree planting programme in Ondo state is destruction by domestic animals. There are positive and significant correlations between sustainable ecosystem management and city greening programme in terms of flood protection, control of erosion, protection of human life, beautification of landscape, replenishing soil nutrient, providing feed for man and animals, providing clean water and improving the quality of air and soil.

\section{Conclusion}

The City greening project has been found to have significant and positive correlation in reducing the impact of climate change and environmental degradation in Ondo state. It has the potentials of improving the social, economic and ecological as -well as spiritual well-being of the people and thus ensuring ecosystem sustainability.

\section{Recommendation}

For the sustainability of the tree planting programmme, the study recommends continuous promotion of the program through the use of extension agents, television and radio programmes. Legislations prohibiting the roaming about of domestic animals should be enforced by task force. The wards should be utilized to distribute seedlings for grassroots spread. The government should continually create appropriate policies and effective institutions at all levels to support people-centred sustainable development.

\section{References}

Adebo G. M. (2014). Effectiveness of E-Wallet Practice in Grassroots Agricultural Services Delivery in Nigeria, -A Case study of Kwara State Growth Enhancement Support Scheme. Journal of Experimental Biology and Agricultural Science. 2, 410-418. http://www.jebas.org/wp-content/uploads/2014/09/Grace-JEBAS.pdf.

Battaglia Michael P. (2008). Multi-Stage Sample http://dx.doi.org/10.4135/9781412963947

Carbon2markets (2014): http://www.carbon2markets.org/content.cfm?ID=26

Cornett, Z. J (1994): Ecosystem Management: Why Now? Ecosystem Management Newsletter, 1(14), June 1994.

Costanza Robert \& Peter P. Principe (1992). Methods to Assess the Effects of Chemicals on Ecosystems Methods for Economic and Sociological Considerations in Ecological Risk Assessment http://www.scopenvironment.org/downloadpubs/scope53/chapter19.htm.

Ecosystem Management Initiatives (EMI, 2014). The Ecosystem Management approach. http://www.snre.umich.edu/ecomgt/emapproach/whatisem.htm. 
Falola, A., \& Adewumi, M. O, (2012): Constraints to Use of Mobile Telephony for Agricultural Production in Ondo state, Nigeria. Journal of Research in Forestry, Wildlife and Enviroment 4(2), 52-63

Fasakin, E. A. (2008). Fish as Food:Yesterday, Today and Forever. Inaugural Lecture Series 48; The Federal University of Technology, Akure. pp 6-7

Haskell, B. D., Norton, B. G., \& Costanza, R. (1992) What is ecosystem health and why should we worry about it? In: Costanza, R., Norton, B.G., and Haskell, B.D. (Eds.) Ecosystem Health: New Goals for Environmental Management, pp. 1-18. Island Press, Washington, D.C.

Food and Agriculture Organization FAO, Chapter 7: Sampling In Marketing Research In Marketing research and information systems. (Marketing and Agribusiness Texts - 4). Agriculture and ConsumerProtection,FAO. http://www.fao.org/docrep/W3241E/w3241e08.htm\#cluster\%20and\%20multistage\%20sampli ng.

Hales DF (2000). Practical steps toward healthier cities and a cleaner global environment.

International Union for Conservation of Nature (IUCN, 2013). Ecosystem Management programmme http://www.iucn.org/about/work/programmes/ecosystem_management/

Maryland Department of Natural Resources (2013). The Benefits of Urban Trees Urban and Community Forestry: Improving Our Quality of Life. http://www.conservationmontgomery.org/Benefits\%2520of\%2520Urban\%2520Trees.pdf.

Muhammad-Lawal, A., Omotesho, O. A., \& Kolade, F. T (2012): An Assessment of Household Vulnerability to economic shocks in South Western Nigeria. International Journal of Development and Sustainability, 3, 701-713. http://isdsnet.com/ijds-v1n3-7.pdf.

Nancy B Grimm, David Foster, Peter Groffman, J Morgan Grove, Charles S Hopkinson, Knute J Nadelhoffer, Diane E Pataki \& Debra PC Peters (2008), The changing landscape: ecosystem responses to urbanization and pollution across climatic and societal gradients http://www.esajournals.org/doi/abs/10.1890/070147

Nix Steve (2014). 10 Reasons Living Trees Are Valuable. http://forestry.about.com/od/treephysiology/tp/tree_value.htm.

Obayelu Abiodun Elijah (2010) Effects of the Emerging Information Communication Technologies (ICTs) on Agricultural Knowledge Transfer to Smallholder Farmers in Nigeria. vol.20, No 2 Information Technology in Developing Countries' Newsletter of the International Federation for Information Processing (IFIP) Working Group 9.4

Okunlola, J. O., Oludare, A. O., \& Akinwalere, B. O. (2011) Adoption of new technologies by fish farmers in Akure, Ondo state, Nigeria . Journal of Agricultural Technology, 7(6), 1539-1548 http://www.ijat-aatsea.com.

United Nation Environmental Policy (UNEP, 2013 )Policy Series on Ecosystem Management Issue No. 7. Putting Ecosystem Management in the Vision of Africa's Development: Towards a 
http://www.unep.org/ecosystemmanagement/Portals/7/Putting\%20Ecosystem\%20Manageme nt\%20in\%20the\%20Vision\%20of\%20Africa\%E2\%80\%99s\%20Development-Policy\%20Pap er.pdf.

USDA Forestry Services (1990), Benefits of Urban Trees. South Carolina Forestry Commission. http://www.state.sc.us/forest/urban.htm.

World Bank (1997). Information needs of small scale farmers in Africa. The Nigerian example Consultative Group on International Agricultural Research, newsletter, 4(3), http://www.worldbank.org/html/cgiar/newsletter/june97/9cgnews.html.

World Commission on Environment and Development (WCED, 1987) 'Our Common Future,

\section{Copyright Disclaimer}

Copyright for this article is retained by the author(s), with first publication rights granted to the journal.

This is an open-access article distributed under the terms and conditions of the Creative Commons Attribution license (http://creativecommons.org/licenses/by/3.0/). 